\title{
CATCHING UP WITH BUILDING INFORMATION MODELING: CHALLENGES AND OPPORTUNITIES FOR QUANTITY SURVEYORS
}

\author{
${ }^{1 *}$ Nurshuhada Zainon, ${ }^{2}$ Faizul Azli Mohd-Rahim, ${ }^{3}$ Nur Mardhiyah Aziz, ${ }^{4}$ Syahrul Nizam \\ Kamaruzzaman, ${ }^{5}$ Sapturinah Puidin \\ ${ }^{1,3}$ Senior Lecturer, Department of Quantity Surveying, Faculty of Built Environment, University of Malaya, \\ 50603 Kuala Lumpur. \\ ${ }^{2,4}$ Associate Professor, Faculty of Built Environment, University of Malaya, 50603 Kuala Lumpur. \\ ${ }^{5}$ Master of Project Management, Faculty of Built Environment, University of Malaya, 50603 Kuala Lumpur. \\ *Corresponding author: *zshuhada@um.edu.my
}

\begin{abstract}
Building Information Modeling (BIM) is gaining a momentum within the construction industry in Malaysia, and worldwide. The 5-dimensional (5D) of BIM has sparked a new way of working in Quantity Surveying practice, transforming the traditional functions of a Quantity Surveyor (QS). This paper highlights the potential use of BIM in Quantity Surveying practices, subsequently discusses the challenges and opportunities gained from BIM advancement in QS profession, especially in Malaysia. Through an extensive literature review and content validation process, the utilization of BIM technology in Quantity Surveying practices works wonder in saving the time of QS have to spend on cost analysis and enhances accuracy; it does not become a threat to the profession, but BIM provides opportunities to direct QS talents towards being more efficient. The outcome of this paper should direct the QS to be BIM-ready, further could become a guide for Quantity Surveying companies' planning in enhancing skills and QS competencies in utilizing BIM hence reinforcing QS role amongst the construction professional discipline.
\end{abstract}

Keywords: Building Information Modeling, Construction, Information Technology, Information Exchange, Quantity Surveyor.

\section{INTRODUCTION}

The construction sector shares 12.2 per cent of world Gross Domestic Product (GDP), with the Global Construction 2025 reported that 70 per cent more construction work will be going on around the world (Branson, 2013). Thus, it is necessary for the construction industry to undergo evolution in the era of globalization with the aim of getting international competitiveness. Owing to its complex in nature and involvement of multi-disciplinary parties, construction industry faces common cost, time, and quality issues. Nevertheless, the rise of Building Information Modeling (BIM) technology has emerged as of the application tools to meet the objective of escalating productivities in a construction project.

BIM is not an alien emergence in global industry nowadays. It is not only known as 3-dimensional tool but it is also equipped with intelligent applications to help delivering a project successfully. BIM also has become as an important enzyme to boost businesses in order to be competitive in local as well as internationally. BIM gained its popularity due to its efficiency benefits in terms of time and cost saving, and increases coordination in information exchange. It is an approach being adopted in managing construction project life cycle activities, from project design, construction, to facilities management (Eastman et al., 2011).

BIM is defined as a digital representation of the physical and functional characteristics of a facility through shared knowledge resource for information, forming a reliable basis for decisions during its life-cycle (Smith, 2014). Started with the use of BIM for architectural design, the conceptual underpinnings of the BIM technology go back to the earliest days of computing, as early as 1962 (Rodrigues, 2015). Today, BIM has become ubiquitous in the 
design and construction fields. In developed regions, the percentage of companies using BIM jumped from 28 per cent in 2007, to 49 per cent in 2009, and for 71 per cent in 2012 (McGraw-Hill Construction, 2012). However in Malaysia, the architectural firms' BIM adoption rate was 20 per cent (Mohd-Nor \& Grant, 2014), and only 10 per cent of quantity surveying firms involved in BIM adoption since BIM was introduced 10 years ago (Ali, AlJamalullail, \& Boon, 2013) Additionally, engineering firms were found being steadily slow implement BIM (Rogers, Chong, \& Preece, 2015). As architectural, engineering, and surveying practices are the main players in BIM working environment, this can be a significant indicator of slow uptake of BIM in Malaysian construction industry as a whole.

In any project, cost and program are key performance indicators, in addition to quality. With the advent of parametric modeling, quantity surveyors (QS) play a significant role in contributing these two fundamental parameters to the modeling process from the outset and add the most value from the earliest stage (Latiffi, Brahim, \& Fathi, 2015). With BIM, the QS can provide detailed and accurate estimates, automate measurement, speed up traditional estimating process, and better capture, manage, and deliver project information. Despite its incredible benefit, BIM uptake among QS is still slow in Malaysia. There are also fear and resistance in the surveying practice towards the changes brought by BIM; where BIM can perform most of the traditional QS job scope which eventually will replace the QS conventional way of working (Matthews, 2011, RICS, 2011, NBS, 2012) which creates a situation that QS is no longer needed in the construction market. Thus, this situation derives an aim of this study which is to provide perspective on future of BIM in quantity surveying practices through reviewing the concerns of Malaysian QS and opportunities that are awaited.

\section{METHODOLOGY}

This study was conducted during September - December 2015 to retrieve articles related to BIM and QS issues literature. No specific key words required as inclusion criteria; the Rich Site Summary (RSS) feeds were referred to get up-to-date information and Google Trends were used to track comprehensive search results over lengthy periods of time continued, hence arranging the topics of discussion related to challenges and opportunities for QS. Articles were retrieved from diverse platform mainly from University of Malaya's online database and Google Scholar within a range of year 2006 to year 2016. Keywords used were "Quantity Surveyors", "Quantity Surveying”, “QS", "Building Information Modeling”, "BIM”, “Challenges”, “Opportunities”, "Prospects”, using a combined search of 'and' and 'or'. The articles include journals, technical reports, and news, written in English or Malay language. The reference lists of each article were reviewed in detail to find additional articles. The results of the searches were recorded in a table form and then were explained further in an essay style. A group of reviewers $(n=46)$ who hold QS post with variety years of experience, independently read articles in full text; they added additional points where necessary to enrich the main findings of challenges and opportunities of BIM in quantity surveying in Malaysia. Consequently the final work was validated by a consensus from a number of Malaysian certified QS ( $n=3$ ). The Malaysian certified QS have worked for Quantity Surveying private consultant firms located in Klang Valley, with more than 15 years' experience in Malaysian construction industry, with minimum of one time involvement in the entire duration of a successful BIM-based construction project.

\section{HISTORY OF BIM IN MALAYSIA}

The adoption of BIM in Malaysia was driven primarily by the private sector since early 2000. However BIM has only become a buzzword when the Jabatan Kerja Raya (Public Works Department, PWD) introduced BIM in construction project planning for public works in 2007 through their BIM Standard Manual and Guideline (Latiffi, et.al, 2013). In an effort to foster BIM environment in Malaysian construction industry, the Construction Industry Development Board (CIDB) has formed the BIM Steering Committee, BIM Roadmap, and BIM Portal, involving policy makers, practitioners, and academicians (CIDB, 2016). In order to help and promote the potential and benefits of BIM, PWD, CIDB and Multimedia Super Corridor Malaysia also offer initiatives namely roadshows, seminars, workshops, on top of affordable training programs (Latiffi, et.al, 2014).

The Construction Research Institute of Malaysia (CREAM, 2012) reported on the earliest BIM projects in Malaysia. The National Cancer Institute of Malaysia in Putrajaya was the first project involved the application of BIM in Malaysia, followed by other projects under BIM Pilot program such as the Healthcare Centre Type 5 Pahang, and Administration Complex of Suruhanjaya Pencegah Rasuah Shah Alam. In these pilot projects, BIM was utilized for site modeling, visualization, design review, clash analysis, 4D schedule and simulation, and record 
modeling (Latiffi., et.al, 2014). Recently, BIM in Malaysia is more likely to be used for complex and high-risk projects (PWD, 2011).

Under the Construction Industry Transformation Plan (CITP) 2016-2020, Malaysian is targeting at imposing the mandatory of BIM on local authority submission by year of 2018 and making BIM as common practice in facilities management by 2019. Whilst by year of 2020, Malaysia has targeting to achieve the status of advanced BIM technology in construction industry.

\section{THE MATURITY OF BIM}

Memon et al (2014) have found that the level of BIM implementation is still low in Malaysia where only about $35 \%$ of construction player are adopting BIM in their projects, with only $26 \%$ of them mentioned adopted BIM throughout all project phases. This low level of BIM implementation was previously identified by Bin Zakaria et al. (2013) where they assessed the maturity of BIM in Malaysian construction industry was in between of Level 0 to Level 1. Among the main reason of the slow growth was due to lack of BIM knowledge and the slow uptake of BIM adoption by Malaysian construction players. While global trending currently, the Western country is moving towards BIM Level 2 especially for UK that targeting to achieve level 2 by 2016 (NBS, 2012). It is undeniable that there are numerous issues and challenges of BIM implementation as per discussed by many researchers (Gardezi, 23014; Bin Zakaria 2013). But, it does not mean that Malaysian construction industry is not capable to stand at the same level with the western companies.

\section{CONCEPT OF BIM}

BIM is defined as a modelling technology and associated set of processes to produce, communicate, and analyze digital information for construction purposes (Abdullah, et.al, 2014). Fundamentally, BIM is not simply a type of software but an integrated approach between human activity to produce digital representation of physical and functional characteristics of a building through relevant software. The common BIM software usually used by the industry players are Revit Architecture, Revit Structural, Revit MEP, Navisworks and Cost-X (Yaakob et. al.,2016). The application of these software enables virtual building to be built in order to simulate, analyze and identify potential problems (Smith, 2007; Teo, et. al., 2015). Uncertainties can be reduced thus making the construction process become efficient.

\section{THE USE OF BIM}

BIM applications span over the entire life cycle of a facility. BIM is applied in project planning, design, preconstruction, construction and post-construction (operations and maintenance) stages. In planning stage, the project team can utilize BIM in analyzing space and understanding the complexity of land regulations and space standards, hence saving time and providing the team more time to create more value-added activities (Azhar, Khalfan, \& Maqsood, 2012). In this phase, advanced 3D laser scanning equipment is used to scan the site to determine the position of existing utilities accurately and then integrate them in the BIM model. On top of intensive use of BIM in designing, the user can perform quantity survey and get detailed estimates accurately which can be measured directly from the 3D models. The user can plan for site logistics and identify potential hazards on site, thus helping in the preparation safety plan. Project managers can benefit from scheduling and monitoring function with the help of 4D and 5D models. In post-construction stage, BIM is used for transferring the data of building (spaces, systems and components) into facility management operations, keeping track of building assets, and enable scheduled maintenance and provides information of building maintenance history.

All the information of functional and physical characteristic of a building and the life cycle of project are included in BIM in a series of smart object, providing better decision support in the process of project development (Azhar et al., 2008). Besides, BIM allow fast and accurate updating of changes, while in conventional 3D CAD, the plans, sections and elevations are used to describe the building as independent 3D views (Broquetas, 2010). Furthermore, the man-hours needed to establish reliable space programs in BIM will be reduced as compared to the conventional technology (Bryde, Broquetas, \& Volm, 2013). BIM also enhances effective communication between the parties involved in the project development (Verster, 2006). For example, the information such as the details of procurement, drawings, submittal processes and other specifications can be linked together in BIM, whereas the conventional approach is paper-based modes of communication. BIM increases the confidence in the completeness of the scope (Latiffi., et.al, 2014). This can be done through a clash analysis to detect conflict, collision, and 
interference due to the model form in scale, 3D space, so the user can visually check the interference in all the systems.

\section{BIM IN QUANTITY SURVEYING PRACTICE}

Quantity surveying is vital in construction field to control and manage the cost throughout the project life cycle. In Malaysia, the Board of Quantity Surveyors (BQSM), the Royal Institutions of Surveyors Malaysia (RISM), and the Royal of Institution of Chartered Surveyors (RICS) are actively promoting the use of BIM among QS. Based on registered QS practice list in Board of Quantity Surveyor's Malaysia website (up until January 12, 2017), there are 362 established QS practice in Malaysia (BQSM, 2017) and only small number of them implementing BIM (Soon, et al., 2016).

Traditionally in practice, taking off and bill of quantities demanded long working hours and effort to be produced, with high-risk of human errors. As the building works are becoming more and more complex, BIM has developed into the mainstream in construction industry in developed country, BIM is expected to be embraced in QS firms to boost up the effectiveness in term of cost and value of construction processes (BCIS, 2011). Quantity surveying requires immense knowledge and skillful interpretation and practical use of the knowledge (Vineeth \& Jenifer, 2014). Implementation of BIM brings opportunity to quantity surveying field in the cost management functions.

Bill of Quantities (BQ) is an important tool to carry out cost management in construction projects. BIM technology provides a fifth dimension (5D) of BIM which can automatically produce BQ (Stanley \& Thurnell, 2014). The collaboration and integration feature of BIM in the automatic production of BQ is an enhancement to the BIM technology. This is effective in eliminating the lengthy and tedious ways of traditional taking off as well as reducing human error. BIM is able to extract exact quantities and areas that are used to estimate cost at any time during the project design stage (Boon, \& Prigg, 2012). Not only that, QS is able to recognize and relate how the total project cost is made up by each elements or spaces of the building through BIM as BIM eases the identification of relationship of quantities versus the locations and costs (Broquetas, 2010). This enhances the competency of QS through the comprehensive knowledge of cost determinants which in turn generate cost estimation with high accuracy and reliability (BCIS, 2011). Any changes in the design will actually being automatically updated through the quantities drawn out from the modified model; it does not require QS to redo the taking off as in traditional method. The cost estimating integration with the BIM design engine allows the project team to execute value management during the design phase efficiently (Gee, 2011).

BIM is capable of providing a more intensive and detailed drawing compared to the traditional 2D drawing where misunderstanding and wrong assumption may be made (Broquetas, 2010). The more comprehensive construction information and more precise BQ can diminish the gap among the project team members. Through understanding on how to extract the quantity from building model, bidders are able to bid with intensely competitive price (Tan \& Abidin 2016).

Through the 5D feature of integrating cost estimation with building model, the estimating job of QS is becoming simple and straightforward as compared to the conventional paper drawing. With BIM, construction field is heading to a paperless construction. Through the Pacific Association of Quantity Surveyors Congress Paper, Soon, et al. (2016) has published a BIM implementation framework for consultant QS firms in a developing country. The framework is still yet to be validated, however it could serve as an elementary guidance for consultant QS to enhance their BIM knowledge and business strategy in implementing BIM. Table 1 summarized the potential use of BIM in QS practice. 
Table 1: The potential use of BIM in QS practice

\begin{tabular}{|l|l|}
\hline \multicolumn{2}{|l|}{ FUNCTION } \\
\hline Quantity take-off & $\begin{array}{l}\text { Open 2D drawings and 3D models for viewing and quantity } \\
\text { extraction. }\end{array}$ \\
\hline Cost estimation & $\begin{array}{l}\text { Reports can be categorized according to areas, blocks, } \\
\text { concrete grades, sub-contractors, and other relevant reports } \\
\text { quickly. }\end{array}$ \\
\hline Cost estimation report & $\begin{array}{l}\text { Detecting clashes during quantity take-off to when several } \\
\text { models (architectural, structural, etc.) are integrated into one } \\
\text { main BIM model. }\end{array}$ \\
\hline Preparation of Bill of Quantity & $\begin{array}{l}\text { Generation of Bill of Quantity using standard method of } \\
\text { measurement }\end{array}$ \\
\hline Cost data & $\begin{array}{l}\text { Establishment of cost data platform for a range of building } \\
\text { projects, hence supporting knowledge management activities. }\end{array}$ \\
\hline Tendering process & $\begin{array}{l}\text { Model checking in controlling the compliance between the } \\
\text { client's requirements and bidder's offers. }\end{array}$ \\
\hline Value management & Facilitate value management and whole life costing. \\
\hline Financial comparative analysis & $\begin{array}{l}\text { Analysis among possible building design options for informed } \\
\text { decision about cost planning and scheduling development. }\end{array}$ \\
\hline Sustainability element & $\begin{array}{l}\text { Formulate financial and environmental implications } \\
\text { simultaneously. }\end{array}$ \\
\hline Feasibility study & $\begin{array}{l}\text { Ease project feasibility study and develop more reliable cost } \\
\text { plan in providing maximize value for clients. }\end{array}$ \\
\hline Procurement process & $\begin{array}{l}\text { Promote informed decision based on digitalized and } \\
\text { comprehensive building information. The best way (so far) to } \\
\text { demonstrate benefits of each steps of the project life cycle. }\end{array}$ \\
\hline Waste management & Waste material could be reduced via project simulations. \\
\hline
\end{tabular}

\section{CHALLENGES OF BIM FOR QUANTITY SURVEYING PRACTICE}

Clearly with the rate of BIM adoption among QS firms, there are challenges spelled out, as follows, in adopting $\mathrm{BIM}$ as it is relatively new to surveying practice (Figure 1):

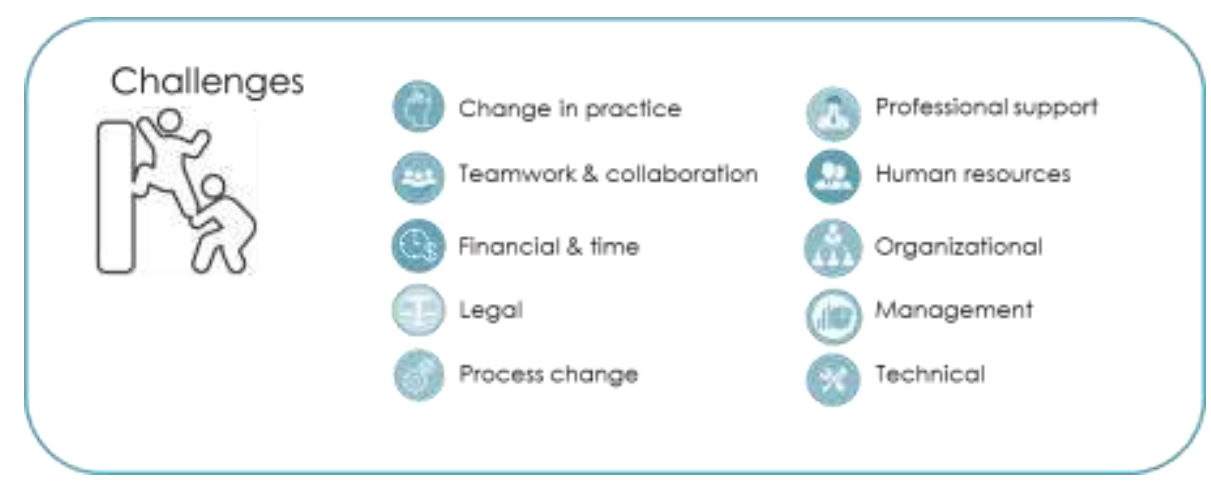

Figure 1: Challenges of BIM for QS practice

\subsection{CHANGE IN PRACTICE}

Firms that can coordinate the design phases and include in-depth knowledge about construction will get the highest advantage as BIM implementation (Latiffi, et al., 2013). The arrangements in contracting that prioritizes excellent cooperation will benefit the owners more when BIM is applied in a project. In addition, when BIM is applied in a certain project, a building model will be constructed and shared among the project team as it is the basis for every 
work process in the project. Knowledge and time are two key components to facilitate this change that will be faced by the companies, as they are also required for every important transformation in technology.

\subsection{TEAMWORK AND COLLABORATION}

Eventhough the implementation of BIM has offered new ways for cooperation between the project team, some problems may arise during its application (Ellul, et al., 2017). For instance, an issue may occur when the method for sharing model information among the team member is not being determined. If traditional drawings on paper have been used by the architect, then a third party will have to construct a model to be used for the estimating and planning of the construction project.

In addition, if the team members use a wide variety of tools for modelling, then the project may require some other tools to move the models between different environments or to combine them together. Hence, this may add complications or cause errors to the project. In order to overcome this issue, the Industry Foundation Classes (IFC) standard can be adapted when data is being exchanged throughout the project life cycle. Other than that, team members can also use a model server that can enable exchange of information between the BIM applications through adaptation of IFC standards. According to Eastman et.al., (2011) and Stanley et. al., (2014), there are two different approach of collaborations; where the project team using the same software from the same vendor or the project team uses an open source software from different vendors. This enables the information to be transferred among the industry players, thus allowing real time changes to be suggested and made during construction (Stanley et. al., 2014).

\subsection{FINANCIAL AND TIME}

In order to implement BIM successfully, firms need to upgrade their hardware, obtain the necessary software, and also require their employees to go for the BIM training in order to transform a 3D environment into a complete BIM system. The firm needs to periodically upgrade their hardware to run the processing software, and this had become a significant barrier particularly for small-medium size enterprises (SMEs) (McGraw-Hill Construction, 2012). It is obvious that the requirement of a big technology component to implement BIM has become a challenge for the surveying industry in Malaysia. Hence, in order to fix technical issues regarding BIM adoption, firms' financial aspect will be affected.

According to Autodesk (2013), the price for Building Design Suite Premium, an entry level software for BIM, was US\$6,825. With the current exchange rate being US\$1.0:RM4.21, that makes the price in Malaysia to be RM28,749.00. Furthermore, the cost calculated beforehand only includes the purchase of the most basic BIM software. The firm has to consider additional costs to train their employees and even hire new employees who are equipped with the knowledge and skills in BIM as they move forward to internalize a new working environment in their firm. It can be deducted that adopting BIM requires the firm to make a huge investment financially as only large organizations can afford the costly technology.

In order to transform a company to being accepting of a new technology such as BIM, a lot of time will be consumed and this is seen as a challenge as construction projects are highly affected by time. In Malaysia's construction industry, there are still limited number of BIM experts. Hence, firms need to allocate time and money in order to find the best experts to assist them in implementating BIM. In addition, firms that decide to send their employees for training in BIM technology would also have to consider the additional time and cost needed for them to master and learn the processes entirely.

\subsection{LEGAL}

Challenges in BIM implementation may arise when the question of ownership and responsibility of the various design, analysis and datasets are asked among the team members (He, et al., 2016). It will be a challenge to determine who is to pay for it and who will be in charge of its precision and accuracy. These challenges are being questioned by the experts when BIM is used in their projects. A building model will be needed by the building owners to enhance the maintenance, renovations and operations once they educate themselves about the benefits of BIM. Furthermore, the absence of BIM contract documents that highlight on the working methods, legal aspects and procurement has limits the applicaton of BIM (Tatt et. al., 2016). 


\subsection{PROCESS CHANGE}

For an organisation to adopt BIM fully, there will be essential and basic changes to its operational processes (Liang, Rowlison, and Zhang, 2016). Once a company successfully adopts BIM, the process of design will be brought forward to the start of the project. QS will involve in the earlier design stage, which enables them to advise the design team and the client regarding the cost implications for every decision that they made (Boon and Prigg, 2012). Having the ability to consider project variation at an early stage, project variation order likely to occur during the construction period (Stanley and thurnell, 2014). In addition, it will also be completed sooner with a completion level higher than those of traditional processes.

\subsection{PROFESSIONAL SUPPORT}

In Malaysia, even though BIM has been known to provide interchange of electronic data without boundaries, the management of professions, trades and industries are still kept fixed in cultural and geographical boundaries, as well as political identities (Gardezi, et al., 2014). In addition, aside from the complex projects, most of the local companies are still being operated by local staffs that are following the local guidelines and mandates. Hence, some potential barriers have been found in various countries including Malaysia, in order for BIM to be adopted in this country. Therefore, it has been proven that in order for BIM implementation to be success, presence of consultants or professionals equipped with the skills and expertise is necessary to support it. This is also aligned with the findings carried out in Singapore by Ho and Rajabifard (2016), where their presence to mould cultural and behavioural in Singapore's BIM strategies produces positive response to chance and accept BIM.

\subsection{HUMAN RESOURCE}

Human resource is required for an effective BIM implementation (Abbasnejad, Nepal, \& Drogemuller, 2016). For any organisation to fully adopt BIM in their projects, their human resource department will need to go through a complementary change in terms of their skills alongside an essential process change within the organisation. Furthermore, there will also be simultaneous increase of competency in the supply chain of the project, which also includes the contractors, designers, and also the developers.

People working in the organization can also be another challenge to face (Monazam, et al., 2016). When the important people in the firm are reluctant to accept the new tools and technology, it makes it harder for them to change their behaviour into liking and accepting it. When the staff resists and show reluctance to BIM, it will become a big challenge to the top management to persuade them to accept the new change in the organization. Their reluctance to learn something new or try the new softwares and technology will be the hardest challenge that the top management will have to overcome in order for BIM to be implemented successfully.

\subsection{ORGANISATIONAL ISSUE}

The role of top management is the most crucial as they have to decide the direction and the plans of action for the organisation to adopt the new technology while reducing the employee's resistance to change (Stanley et. al., 2014). In addition, the employees will be motivated as they witness the organisation's dedication in fulfilling their responsibilities seriously. Motivating the employees is one of the ways to help decrease their reluctance in accepting the new technology as well as encouraging them to be more confident in trying out the IT applications themselves (Wang \& Song, 2016).

In addition, there are some organisations that are scared to take the risk in changing their business process by adopting BIM (Pittard \& Sell, 2016). They worry about the huge uncertainty that may or may not affect their established firms, as well as the large cost that they have to bear. Other than that, managing the big change in terms of technology may also cause a challenge for the managers. The staff may feel threatened or anxious with the adoption of the new technology as they might think that their roles will be taken over by the softwares and hardwares that BIM requires in order to function. Hence, managers must know how to tackle the technology change in the organisation.

Furthermore, another challenge that will be faced by the organisation is that their well-recognized firms will be affected by the new technology that comes with BIM implementation (Liang, Rowlison, and Zhang, 2016). When a new technology is adopted, the business processes of a firm will also be affected, which can also impact the firm's 
significant rate of output. This, in turn, will also increase the risk in producing the outcomes of a project as well as the client's preset goals.

\subsection{MANAGEMENT}

Currently, there have not been any specific directions or orders in ways to use or implement BIM. There are no clear instructions on how to use and apply BIM in construction practises (Yaakob, Wan, \& Radzuan, 2016). Even though a few software companies have developed some products to help with the implementation of BIM, they have only managed to cover the aspects of quantity instead of implementing it as a whole. Therefore, the firm can appoint managers to lead a team responsible for planning the BIM implementation by prioritizing budget, cost and time as their guidance. Other than that, an adoption plan could be developed to predict how the future implementation changes will impact the firm's partners and clients and also how it will affect its internal departments.

For BIM to be adopted by firms, there must be some clear and specific guidelines to be followed and the steps to implement BIM must be standardized. Another management challenge is the question that arose among the stakeholders, which is who shall be responsible for developing the models and how the costs will be distributed. Hence, to clear this issue, solutions have to be created by researchers, vendors and professional organizations together so that the use of BIM will increase in the Malaysian construction industry (Latiffi, Mohd, \& Rakiman, 2015c).

\subsection{TECHNICAL}

Hong, et al. (2016) reported that it is hard to adopt new information technology (IT) in the industry due to technical reasons. Problems such as the lack of support system, difficulty to understand the complex softwares and also the low number of skilled technical experts are among the reasons (Latiffi et. al., 2015b). Furthermore, BIM may have been accepted at a low rate because of the need for detailed and precise models to fix the issue of interoperability. Other than that, in order for important information to be communicated and integrated successfully among the components, there is a requirement for excellent practical strategies to be developed. This could lead to another technical reason as to why BIM has not been the choice for some firms. In addition, they also have to ensure every data developed is computable as it is part of BIM's technical requirements.

\section{OPPORTUNITIES OF BIM FOR QUANTITY SURVEYORS}

As illustrated in Figure 2, the competitiveness of QS is highly improved with the adoption of BIM. Cost estimation can be done through the quantities extraction at any stages during the design phase, (Boon, 2009), which enhanced the efficacy of a QS. For example, using the conventional way, it takes couple of days for QS to finish up the estimate for the earthwork, but using BIM the extracting of the quantities takes less than an hour. When variations arise, QS can re-extract the quantities from the modified model and avoid the tedious human measurement. A competent and high efficiency QS poses better chances in surveying field. Not only that, the improved quality of estimation produces quality tender which will enable the QS to help company to open up more business opportunity and manage to get repeat business by winning the tender (Latiffi, Brahim, \& Fathi, 2015a).

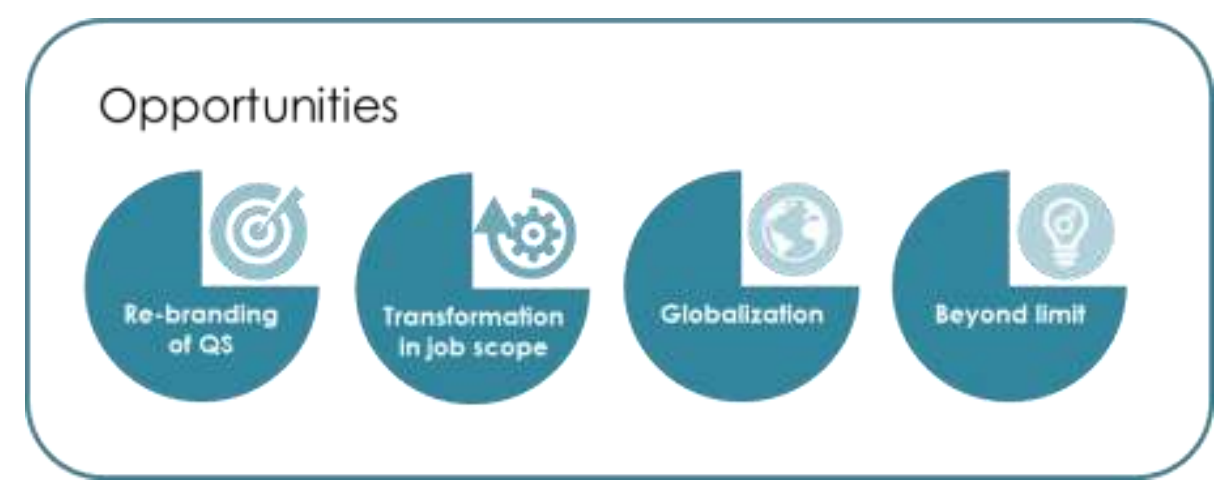

Figure 2: Opportunities of BIM for QS 


\subsection{RE-BRANDING OF QUANTITY SURVEYOR}

With application of BIM, it is an era for Malaysia QS to rebranding their job from a profession that only prepares $\mathrm{BQ}$ to a higher end consultants. In future, BIM will turn QSs to profession doing cost management, in term of cost modelling and also general advisor in pre-contract stages. QS will no longer be labelled as "Construction Industry Accountant", but also will be known as construction industry legal specialist as they are the one who is responsible to handle legal issues such as dispute resolution and giving legal advices regarding construction contract matters. QSs' proactive and knowledge based advices taking in all the aspects and situations of a project in consideration is important to the client (Verster, 2006).

Not only limited to that, by eliminating the lengthy quantity take off by BIM, QSs can now engaged in contruction management aspects such as value management and risk management. Other than that, QSs also involve in giving advices on health and safety and also quality control (Cunningham, 2014). Hence, BIM has provide the opportunity for QSs in Malaysia surveying to be rebrand from the root as a measuring profession to a profession serving towards value-added into a project. BIM aids the Malaysian surveyors to handle numbers, measurements and the rigid measurement rules with ease and helps them to think more on strategy by utilising critical thinking.

\subsection{TRANSFORMATION IN JOB SCOPE}

Through the benefits brought by BIM to the surveying field in term of ease of quantity take off (Davidson, 2008), QS in malaysia do not need to spend time to do measurement and find out the dimensions in from a $2 \mathrm{D}$ drawing. BIM offers improved information interns of data visualisation, reliable database and data coordination that is necessary in producing reliable cost estimates (Ismail et. al., 2016). Unnessary assumptions and human errors can also be avoided. Now, with a highly accurate BQ produced in a very short time, QS is freed up to do more on cost management not in term of the manual taking off and adding up. There is no doubt that the QS still need basic skills regarding measurement to make use of the BIM technology, however, QS now saves more time and they are now no longer a wetware calculator, but they need to think more on what client's needs and wants. There are so many aspects that a QS need to cover.

QS not only provide advices on the construction methods and construction materials, QS also need to handle the legal issues. QS also have to be major on feasibility studies, value management, cost planning, tendering and dispute resolution (Gee, 2011). This opens the gate for Malaysian QS to involve in a construction project more comprehensively, but not major in measurement like current industry practice. This is heading to the QS job perspective in developing country, the best example to cite will be United Kingdom.

\subsection{GLOBALIZATION}

BIM opens up the gate for QS in Malaysia to have a same communication platform. In conventional way of current Malaysia surveying practices, QS are using the Standard Method of Measurement of Building Works Second Edition (SMMS) as their measurement rules reference. In projects involving multi-countries, different standard methods of measurement are used in different regions (Gardezi, et al., 2014). According to Heiskanen (2014), the very first international survey carried out in 2013 revelaed that consultants that do not adopt BIM were struggled to secure international project. As technology has advanced, BIM softwares has ease QS works, where it offers a set of of requirements which is defined from the viewpoint of cost estimating and planning to enable the quantity surveyor to use BIM (BCIS, 2011). This is one of the contribution factors to the success for local contractor to strive for success in international projects as the coordination and communication are greatly improved through BIM (Broquetas, 2010).

\subsection{BEYOND LIMIT}

Malaysian surveying industry produces QS that are expert in measurement with local standard rules of measurement. When they are to engage in international project or being posted to other branch of company overseas, they requires intensive training to learn the QS practices in other country (Vineeth \& Jenifer, 2014). Hence, the possibility of a QS to venture into international market is hard and limited due to the resistance to be accepted by international surveying market as different places poses different practices. BIM is seen as a solution to this problem. It is easier for the Malaysian surveyors to venture into international market as BIM is linked to software to enabe extraction of quantity (Stanley \& Thurnell, 2014). When the surveyors know how to handle the software, it takes a very short time for a QS to catch up with the job scope especially in producing accurate BQ. 
The other aspects such as the legal aspect (Olantuji, 2011) and also the risk and value management (Peterson, et.al, 2011) is a broad knowledge and no region boundary as it is something critical and analytical which requires QSs' to think out of the box.

Therefore, Azhar, Khalfan, \& Maqsood (2012) highlighted that BIM is a tools that enables Malaysian surveyors to go beyond the limits, they are no longer bound to just one country. They can hop to different countries and still serve as QS with ease. BIM enables QSs not to be rooted and stucked in to serve in one country and cannot go far. To see from other perspective, surveyors and experts from other places can also be imported to gain their strength and power so that they can be adopted in Malaysia surveying field. This is a vice versa relationship.

\section{CONCLUSION}

Through the continuous advancement in technology, construction industry cannot deny the changes but have to adopt it. BIM, as the latest trend in construction industry, can help to improve the construction process in so many ways such as providing rapid visualization, giving better decision support, providing rapid and accurate changes updating, providing better and efficient communication and so on. All these aspects meant to improve and secure the overall quality of the project, making local construction project to be more competent in international construction industry. BIM not just emphasize on the design stages, it is actually a comprehensive technology which covers throughout the pre-construction stage, construction and postconstruction stage.

The challenges that come with BIM implementation affect every sector of the organisation that wish to adopt it. There are challenges in teaming and collaboration as well as the question of documentation ownership and production. Furthermore, the implementation issues, use of information, changes in process as well as financial and time considerations are some other challenges that must be faced by the organisations. As people are one of the most tangible factors, the challenges will greatly affect the human resource and organisational issues of the firms. In addition, the challenges that may be faced by the organisation could also be categorized into management and technical challenges. It is clear to see that BIM carries along a lot of issues and challenges with its implementation. However, if an organisation can manage smartly and take all the right steps in overcoming them, it will get to experience the convenience and powerful technology that BIM can offer. Now leaps far and see a bigger picture on the opportunities for Malaysian surveying practices with BIM implementation. BIM aids in the quantity surveying practices in their works on preparing BQ, cost estimation, updating of cost and even in tendering process. With all this, BIM eventually is a way for the QS to get out from the conventional method of doing quantity take off which is very tedious and which in turn will transform the job scope of surveyors, making them to be rebrand as a higher end consultants. This is not the end of their opportunity as BIM provides a platform for local surveyors to integrate internationally with other surveyors. Hence, local surveyors are not nationally restricted. In fact, they can go beyond the limit and works in international established companies or projects with ease. This is also a golden opportunity for local surveying practices to immerse with new strength and knowledge from other places as BIM ease effective communication.

\section{ACKNOWLEDGEMENT}

This research is supported by British Council Newton-Ungku Omar Fund Institutional Links (ID: 172726659) and University of Malaya Research Fund Assistance (Grant no: BKP028-2016)..

\section{REFERENCES}

Abbasnejad, B., Nepal, M., \& Drogemuller, R. (2016). Key Enablers for Effective Management of BIM Implementation in Construction Firms. Creating built environments of new opportunities, 1, 622.

Abdullah, S.A, Sulaiman, N, Latiffi, A.A, \& Baldry, D. (2014). Building Information Modeling (BIM) from the Perspective of Facilities Management (FM) in Malaysia. Universiti Tun Hussein Onn Malaysia, retrieved from http://eprints.uthm.edu.my/5425/1/IRERS_2014_2_U.pdf.

Ali, K.N., Al-Jamalullail, S.N.N.S.I, \& Boon, T.C (2013), Building Information Modeling Awareness and Readiness among Quantity Surveyors and Quantity Surveying Firms, Universiti Teknologi MalaysiaRoyal Institution of Surveyors Malaysia, Technical Paper. 
Autodesk. (2013). Autodesk Building Design Suite. Retrieved from http://usa.autodesk.com/autodesk-buildingdesign-suite/compare/.

Azhar, S., Khalfan, M., \& Maqsood, T. (2012). Building information modelling (BIM): now and beyond. Australasian Journal of Construction Economics and Building, 12(4), 15-28.

Bank Negara Malaysia (2015), Economic and Financial Developments in Malaysia in the First Quarter of 2015, retrieved from http://www.bnm.gov.my/files/publication/qb/2015/Q1/1Q2015_fullbook_en.pdf.

BCIS. (2011). RICS 2011 Building Information Modelling Survey Report. Retrieved from http://www.bcis.co.uk/downloads/RICS_2011_BIM_Survey_Report.pdf

Bin Zakaria, Z., et al (2013). "Exploring the adoption of Building Information Modelling (BIM) in the Malaysian construction industry: A qualitative approach." International Journal of Research in Engineering and Technology, Vol.2 (8), 384-395.

Boon, J. (2009). Preparing for a BIM Revolution.13th Pacific Association of Quantity Surveyors Congress (PAQS 2009). (P.35).

Boon, J., \& Prigg, C. (2012) 'Evolution of quantity surveying practice in the use of BIM - the New Zealand experience', Joint CIB International Symposium of W055, W065, W089, W118, TG76, TG78, TG81 and G84, viewed 5 July 2013 http://www.irbnet.de/daten/iconda/CIB DC25601.pdf

Branson, A (2013), Global Construction 2025, Building.co.uk, retrieved from http://www.building.co.uk/globalconstruction-2025/5057217.article.

BQSM (2017), Registered QS Practice, retrieved from https://www.bqsm.gov.my/index.php/en/qs-registry$\underline{\text { 2/registered-qs-practices }}$

Broquetas, M. (2010). Using BIM as a project management tool: how can BIM improve the delivery of complex construction projects?. Master degree dessertation, University of Applied Sciences, Stuttgart.

Bryde, D., Broquetas, M., \& Volm, J. M. (2013). The project benefits of building information modelling (BIM). International Journal of Project Management, 31(7), 971-980.

CIDB (2016). BIM Training, retrieved from http://www.bimcenter.com.my/.

CREAM (2012). A Case Study of BIM Implementation in Malaysia, retrieved from http://www.myconstructionresearch.com/index.php/publication/integrated-design-deliverysolution/file/12-bim-implementation-in-malaysia.

Davidson, A., R. (2008). A study of the deployment and impact of Building Information Modelling Software in the Construction Industry. Retrieved from http://www.engineering.leeds.ac.uk/e engineering/documents/AndrewDavidson.pdf

Eastman, C., Teicholz, P., Sacks, R., \& Liston, K. (2011), BIM handbook: A guide to building information modeling for owners, managers, designers, engineeris, and contractors, Wiley: New Jearsey.

Ellul, C., Boyes, G., Thomson, C., \& Backes, D. (2017). Towards Integrating BIM and GIS-An End-to-End Example from Point Cloud to Analysis. In Advances in 3D Geoinformation (pp. 495-512). Springer International Publishing.

Gardezi, S, et al. (2014) "Challenges for Implementation of Building Information Modeling (BIM) in Malaysian Construction Industry." Applied Mechanics \& Materials, 567.

Gee, C. (2011). The influence of buidling information modelling on the quantity surveying profession.

He, Q., Wang, G., Luo, L., Shi, Q., Xie, J., \& Meng, X. (2016). Mapping the managerial areas of Building Information Modeling (BIM) using scientometric analysis. International Journal of Project Management. 
Ho, S., \& Rajabifard, A. (2016). Towards 3D-enabled urban land administration: Strategic lessons from the BIM initiative in Singapore. Land Use Policy, 57, 1-10.

Hong, Y., Sepasgozar, S. M., Ahmadian, A. F. F., \& Akbarnezhad, A. (2016, January). Factors influencing BIM Adoption in Small and Medium Sized Construction Organizations. In ISARC. Proceedings of the International Symposium on Automation and Robotics in Construction (Vol. 33, p. 1). Vilnius Gediminas Technical University, Department of Construction Economics \& Property

Ismail, N. A. A., Drogemuller, R., Beazley, S., \& Owen, R. (2016). A Review of BIM Capabilities for Quantity Surveying Practice. In MATEC Web of Conferences (Vol. 66, p. 00042). EDP Sciences.

Latiffi, A.A., Brahim, J, Mohd, S, Fathi, M.S. (2014). The Malaysian Government's Initiative in Using Building Information Modeling (BIM) in Construction Projects, ASEA-SEC-2, Bangkok, November 3-7.

Latiffi, A. A., Brahim, J., \& Fathi, M. S. (2015a). Roles and Responsibilities of Construction Players in Projects Using Building Information Modeling (BIM). In IFIP International Conference on Product Lifecycle Management (pp. 173-182). Springer International Publishing.

Latiffi, A.A., S. Mohd and J. Brahim (2015b). Application of Building Information Modeling (BIM) in the Malaysian Construction Industry: A Story of the First Government Project.

Latiffi, A. A., Mohd, S., \& Rakiman, U. S. (2015c). Potential Improvement of Building Information Modeling (BIM) Implementation in Malaysian Construction Projects. In IFIP International Conference on Product Lifecycle Management (pp. 149-158). Springer International Publishing.

Latiffi, A.A, Mohd,S, Kasim, N, \& Fathi, M.S. (2013). Building Information Modeling (BIM) Application in Malaysian Construction Industry. International Journal of Construction Engineering and Management, 2(A), 1-6.

Liang, C., Lu, W., Rowlinson, S., \& Zhang, X. (2016). Development of a Multifunctional BIM Maturity Model. Journal of Construction Engineering and Management, 06016003.

NBS. (2012). National BIM Report 2012. Retrieved from http://www.thenbs.com/pdfs/NBSNationalBIMReport12.pdf

Matthews, D. (2011). Rise of the Machines: BIM and QS's. Retrieved from www.blackenewport.co.uk/bna-newsand-media.asp?id=90

McGraw-Hill Construction (2012), The business value of BIM in North America: Multi-year trend analysis and user ratings smart market report, retrieved from http://bimforum.org/wp-content/uploads/2012/12/MHCBusiness-Value-of-BIM-in-North-America-2007-2012-SMR.pdf.

Memon, A. H., Rahman, I. A., Memon, I., \& Azman, N. I. A. (2014). BIM in Malaysian construction industry: status, advantages, barriers and strategies to enhance the implementation level. Research Journal of Applied Sciences, Engineering and Technology, 8(5), 606-614.

Mohd-Nor, M.F.I \& Grant, M.P. (2014). Building Information Modeling (BIM) in the Malaysian Architecture Industry, WSEAS Transactions on Environment and Development, Vol.10, 264-273.

Monozam, N. H., Monazam, H. H., Hosseini, M. R., \& Zaeri, F. (2016). Barriers to Adopting Building Information Modeling (BIM) within South Australian Small and Medium Sized Enterprises. Project Management Development-Practice and Perspectives, 125.

Olatunji, O. A. (2011). A preliminary review on the legal implications of BIM and model ownership. Journal of Information Technology in Construction (ITcon), 16(40), 687-696.

Peterson, F., Hartmann, T., Fruchter, R., \& Fischer, M. (2011). Teaching construction project management with BIM support: Experience and lessons learned. Automation in Construction, 20(2), 115-125.

Pittard, S., \& Sell, P. (2016). 3 Risk and risk management. BIM and Quantity Surveying, 51. 
PWD (2011). Laporan Tahunan Jabatan Kerja Raya 2011, pp 28-29. Retrieved December 6, 2015, from http://www.jkr.gov.my/var/files/File/dokumen/laporan_tahunan_jkr_2011.pdf.

Rodrigues, R. F. O. (2015). Otimização do processo de pré-dimensionamento de fundações diretas com recurso à metodologia BIM.

Rogers, J, Chong, H.Y, \& Preece, C. (2015). Adoption of Building Information (BIM) technology: Perspectives from Malaysian engineering consulting services firms. Engineering, Construction, and Architectural Management, 22(4), 424-445.

Smith, P. (2014), BIM implementation - global strategies. Procedia Engineering, 85, 482-492.

Soon, L.T, Leong B.T, Ang, F.L, and Hassan, H (2016), A preliminary BIM Implementation Framework for Consultant Quantity Surveyor Firms in a Developing Country, retrieved from the Pacific Association of Quantity Surveyors website, http://www.paqs.net/sites/default/files/a\%20preliminary\%20bim\%20implementation\%20framework\%20 for $\% 20$ consultant $\% 20$ quantity $\% 20$ surveyor $\% 20$ firms $\% 20 \mathrm{in} \% 20 \mathrm{a} \% 20$ developing $\% 20$ country.pdf

Stanley, R and Thurnell, D (2014) 'The benefits of, and barriers to, implementation of 5D BIM for quantity surveying in New Zealand', Australasian Journal of Construction Economics and Building, 14 (1) 105117

Tatt, S. L., \& Abidin, H. H. N. Z. (2016). Quantity Surveying Firm Change Model In Managing The Constraints Of Bim Implementation. RESEARCH JOURNAL OF FISHERIES AND HYDROBIOLOGY, 11(3), 105110

Teo, E A L, Ofori, G, Tjandra, I K and Kim, H (2015) The potential of Building Information Modelling (BIM) for improving productivity in Singapore construction In: Raidén, A B and Aboagye-Nimo, E (Eds) Procs 31st Annual ARCOM Conference, 7-9 September 2015, Lincoln, UK, Association of Researchers in Construction Management, 661-670.

Verster, J. J. P. (2006, April). Managing cost, contracts, communication and claims: A Quantity Surveying perspective on future opportunities. In Proceedings of 1st ICEC \& IPMA Global Congress on Project Management, 5th World congress on Cost Engineering, Project Management and Quantity Surveying (pp. 23-26).

Vineeth, R., \& Jenifer, P. (2014). Role of Building Information Modelling ( Bim ) in Quantity Surveying Practice. International Journal of Civil Engineering and Technology, 5(12), 194-200.

Wang, G., \& Song, J. (2016). The Relation of Perceived Benefits and Organizational Supports to User Satisfaction with Building Information Model (BIM). Computers in Human Behavior.

Yaakob, M., Wan, W. N. A., \& Radzuan, K. (2016). Critical Success Factors to Implementing Building Information Modeling in Malaysia Construction Industry. International Review of Management and Marketing, 6(8S). 